\section{An integrated approach to assess the vulnerability to erosion in mangroves using GIS models in a tropical coastal protected area}

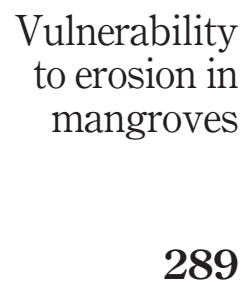

José Guilherme Moreira Simões Vieira, Joana Salgueiro, Amadeu Mortágua Velho da Maia Soares, Ulisses Azeiteiro and Fernando Morgado

Department of Biology and CESAM Centre for Environmental and Marine Studies, University of Aveiro, Aveiro, Portugal
Received 14 May 2017 Revised 17 September 2017 9 December 2017 Accepted 17 December 2017

\begin{abstract}
Purpose - The development of models that allows the evaluation and prediction of erosion processes is an important tool for the management and planning of coastal systems. Mangrove forests systems are under threat by the impacts of erosion, which is also intensified by human activity (and aggravated in the scenarios of global warming and climate change). The purpose of this paper is to develop a model of geographic information systems (GIS) that can be used for any estuary area, but it can also be used for mangroves.
\end{abstract}

Design/methodology/approach - This paper uses georeferentiation which is defined as a set of parameters that best characterize the mangrove areas: elevation (m); geomorphology; geology; land cover; anthropogenic activities; distance to the coastline $(\mathrm{m})$ and maximum tidal range $(\mathrm{m})$. Three different methods are used to combine the various vulnerability parameters, namely, DRASTIC index, analytical hierarchy process (AHP) and square root of the geometric mean.

Findings - The three approaches presented in this work show different types evaluating vulnerability to erosion, highlighting a stronger overvaluation of the areas presented with a high vulnerability, through the use of DRASTIC index when compared with two other approaches. The use of the AHP shows similarity to the square root of the geometric mean model, but the AHP also presents a higher percentage of vulnerable areas classified as having medium to very high vulnerability. On the other hand, the use of square root of the geometric mean led to a higher percentage of areas classified as having low and very low vulnerability.

Research limitations/implications - These three qualitative models, based on a cognitive approach, using the set of parameters defined in this research, are a good tool for the spatial distribution of erosion in different mangroves in the world.

Originality/value - Global warming and climate change scenarios require adaptation and mitigation options supported by science-based strategies and solutions.

Keywords Climate change, Geographical information system, Vulnerability, Coastal erosion, Mangroves, Population displacement

Paper type Research paper

(C) José Guilherme Moreira Simões Vieira, Joana Salgueiro, Amadeu Mortagua Velho da Maia Soares, Ulisses Azeiteiro and Fernando Morgado. Published by Emerald Publishing Limited. This article is published under the Creative Commons Attribution (CC BY 4.0) licence. Anyone may reproduce, distribute, translate and create derivative works of this article (for both commercial \& noncommercial purposes), subject to full attribution to the original publication and authors. The full terms of this licence may be seen at http://creativecommons.org/licences/by/4.0/legalcode 
IJCCSM 11,2

290

\section{Introduction}

There is uncertainty about the ways in which climate change will impact natural and human systems and the way in which society might perceive and respond to these changes (McLeman and Smit, 2006; Nicholls and Tol, 2006; Black et al., 2008; PerchNielsen et al., 2008; Warner et al., 2008). Certainly the livelihoods of many people around the world and some particular (ecos) systems and sectors are likely to be under increasing pressure and affected by impacts from climate change (IPCC, 2007b, 2007c). Mangrove forests cover large parts of the tropical and sub-tropical shores in the world (Spalding et al., 1997) and are among the most important and biologically most productive ecosystems as they provide important goods and services to mankind as well as marine and coastal systems. They are one of the most biologically diverse forests and are often part of a larger sea defense system (McIvor et al., 2012). These forests protect the coastline and prevent erosion, help stabilize the coastline and reduce the impact of natural disasters such as tsunamis and storms. By collecting sediment from the rivers and streams and decelerating the flow of water, forests contribute toward reducing their impact on coastal infrastructure and the risk of flooding, by buffering the energy of these incoming waters (Krauss et al., 2008; Zhang et al., 2012), and erosion (Thampanya et al., 2006). In addition, mangrove forests provide nursery and shelter for various marine pelagic species, food, medicinal products, wood fuel and construction material for local communities, and the high productivity of fisheries and significant exports of carbon fixed to coastal areas (McLeod et al., 2011).

Climate change is likely to have a substantial impact on mangrove ecosystems through processes including rise in sea levels, increase in water events, changes in ocean currents, increase in storminess, increase in temperature, changes in precipitation and increase in $\mathrm{CO}_{2}$ levels in addition to the health of the functionally linked neighboring ecosystems and human responses to climate change (Gilman et al., 2008; McKee et al., 2012; Ward et al., 2016). These factors are spatially variable and dependent on local scales [climate, geomorphology, biodiversity, forest structure, tidal range and climate change impacts (Ellison, 2015)]. The degradation of mangrove forests is a growing problem in various mangroves worldwide. Waves, tides, rivers and rainfall affect water circulation by generating turbulence and advective longitudinal mixing, trapping coastal water and influencing the rate of erosion and deposition of sediments on which mangroves grow. Important causes for this degradation are human activities such as intensive shellfish farming and cutting down of the mangroves for wood (Alongi, 2002; Field, 1995). Understanding the key processes occurring in the mangrove is important for the preservation, local management and rehabilitation (Field, 1995).

Determination of possible impacts in future must be considered against a background of natural disturbance, such as cyclones and other storms, lightning strikes, tsunami, floods, subsidence and drought (Smith et al., 1994; Gilman et al., 2008). Several studies have described the attenuation of wind and swell waves by mangroves (Burger, 2005; Brinkman, 2006). The factors known to affect the reduction in wave height as waves pass through mangroves include water depth, which is a function of topography/bathymetry and tidal phase, wave height and various aspects of the structure of mangrove trees depending on their species, age and size (Woodroffe, 2002). Some numerical models (Vo-Luong and Massel, 2008; Suzuki et al., 2012) have been used to model wave attenuation by mangroves, and the predictions of these models match observed wave attenuation reasonably well. Moreover, the roots, stems and canopies attenuate and dissipate wave energy, acting as a natural sea defense mechanism (Schiereck and Booij, 1995). 
Several natural processes can promote subsidence, which are often augmented by anthropogenic reasons. This includes tectonic changes in erosional control on a river or coast, sediment compaction, changes in farming practices (e.g. irrigation), deforestation, mining, groundwater or hydrocarbon extraction and changes to coastal management such as levees or embankments (Ericson et al., 2006; Syvitski, 2008). Together these factors can result in ground subsidence or uplift/rising land or more commonly a combination of the two. Net subsidence is the combined effect of land sinking and land rising, including sedimentation. Subsidence can result in increased flooding and subsequent shoreline retreat and land loss. It can reduce the efficiency of defenses and increase salinization, affecting agriculture, having the potential to affect millions of people and many who may be in poverty (Syvitski, 2008; Syvitski et al., 2009). Rising sea levels causes similar effects, and these processes reinforce each other.

Deficiencies of precipitation over time can develop different patterns of droughts (WMO, 2011). Increases in the frequency, duration and/or severity of drought and heat stress associated with climate change could fundamentally alter the composition, structure and biogeography of forests in many regions. Of particular concern are increases in tree mortality associated with climate-induced physiological stress and interactions with other disturbances such as pest outbreaks and fire (Allen et al., 2001). Susceptibility of forest ecosystems to drought is mainly determined by site (soil texture, soil depth and waterholding capacity) and stand characteristics (i.e. leaf area, species composition and rooting depth), stand management and human pressure (Seidl et al., 2011).

Simulation studies of prediction models developed for coastal erosion are crucial for preventing the degradation of coastal ecosystems (Lewis and Nyamulinda, 1996), and integrated solutions for uncontrolled population growth and urbanization in coastal areas, poverty and economic inequality in coastal communities are urgently needed. In a global warming and climate change scenario with impacts on the infrastructure leading to population displacement require adaptation and mitigation options supported by sciencebased strategies and solutions. Vast literature is available on climate change, migration and displacement and environmentally displaced people, and research is available on the linkages between environmental change, livelihoods and forced migration (Kibreab, 1997; Paavola and Adger, 2006; Black et al., 2008; Warner and Laczko, 2008a) and climate change adaptation indicators and metrics (Lamari et al., 2016). Studies of climate-induced migration have in the past commonly calculated the numbers of "environmental refugees" by projecting physical climate changes, such as sea level rise or rainfall decline, on exposed population (Nicholls and Tol, 2006; Warren et al., 2006). Chances are high that many semiarid areas will suffer a decrease in water resources owing to climate change (IPCC, 2007b, 2007c). These impacts contribute to serious erosion risk caused by environmental shocks (droughts, floods, loss of land, rising temperatures and rising sea levels) with further implications to forced population displacement and migration, increasing pressure on urban infrastructure and services and economic growth, increasing the risk of conflicts and social unrest and spreading health risks (Pelling and Hight, 2005; Barnett, 2006; Paavola and Adger, 2006; Reuveny, 2007; Wilbanks et al., 2007).

Several mathematical models have been developed and improved over the past 20 years to better understand the spatial distribution of erosion and predict the magnitude of soil loss by erosion through the use of tools that enable the assessment of soil loss, and to assist in the management of risk areas, especially in places where the soil loss has been above the sustainable limits (Lewis and Nyamulinda, 1996; Keisler and Sundell, 1997; Area et al., 1998; Angima et al., 2003; Gomes, 2007; Amorim et al., 2010; Dumas et al., 2010; Nas et al., 2010; Pereira and Coelho, 2013). These models project countless types of results in an attempt to
Vulnerability to erosion in mangroves

291 
IJCCSM 11,2

292 quantify the risk and vulnerability, resulting in risk and/or vulnerability maps, due to the possibility of selecting a set of parameters that are closer to erosion reality (Boulanger and Brechet, 2005; Adger, 2006; Berkhout et al., 2006; Pereira and Coelho, 2013).

Integrated models to assess vulnerability to erosion can be useful in planning population displacement, allowing the prediction of the magnitude of soil loss by erosion and quantifying the risk and vulnerability and the impacts to environment and populations (Jones, 2001; Freeman and Kunreuther, 2002; Warner and Laczko, 2008a, 2008b; Warner et al., 2008). Cognitive approaches have been adopted to be able to better understand the spatial distribution of erosion (Amorim et al., 2010). Thus, numerous models that describe the vulnerability of coastal erosion in various parts of the world have been developed by aggregating a set of defined parameters. The combination of parameters varies from author to author, using the algorithm that best describes the global vulnerability of the study areas. Gornitz (1991) used the square root of the geometric mean for calculating the coastal vulnerability index (CVI) by applying the square root of the product of each variable divided by the number of variables. The author supports the use of square root that softens the range of values for the single use of the product of the variables, representing results closer to reality. Unlike Gornitz (1991) and Coelho et al. (2006), who used a more complex algorithm for calculating the overall vulnerability of Aveiro Coast, in which the distance of the coastline is combined with the other variables through a weighted linear combination, Rao et al. (2009) have combined various parameters of the coast of Andhra Pradesh, India, through the use of a weighted linear combination (each parameter was assigned an arbitrary weight, where the highest weights were conceived to the parameters with high importance). The evaluation of erosion tendency is required to establish the magnitude and extent of the problem to draw the attention of several entities, to identify the impacts of erosion and understand its nature and its causes and to define an appropriate approach for management and selection of projects for the establishment of technologies to mitigate/ eliminate the causes of erosion. This evaluation, which includes quantifying and mapping a set of variables that contribute to the evaluation of erosion risk caused by environmental shocks (droughts, floods, loss of land, rising temperatures and rising sea levels), should be considered in the implications for forced population displacement and migration and in the resulting increase in pressure on urban infrastructure and services and economic growth, increase in the risk of conflicts and social unrest and spread of health risks.

The purpose of the model developed in this study is to spatialize the distribution of global vulnerability of coastal erosion in the region. It is a qualitative method, based on a cognitive approach, being defined by a number of factors based on literature revision (Gornitz, 1991; Gornitz et al., 1994; Edet, 2004; Coelho et al., 2006; Szlafsztein and Sterr, 2007; Rao et al., 2009). The approach developed consists of three stages:

(1) definition of vulnerability parameters;

(2) rating parameters over a range of values; and

(3) combination of parameters.

This paper aims to develop a model of geographic information systems (GIS) that can be used for any estuary area, but it can also be used for mangroves, using some of the parameters defined in this paper; the same models that best suit the complexity of mangroves for determining the vulnerability of coastal erosion mangrove systems to permit planning and management of population's displacement can also be used. It was developed 
a multidisciplinary approach with the appropriate information, existing and validated models. The newly developed model represents the vulnerability to erosion and is a fundamental tool for the management of these systems and further use on planning population's displacement.

\section{Research methodology}

\subsection{Study area}

The study was conducted in the estuarine system of Cananéia-Iguape on the south coast of São Paulo, which is formed by a complex set of environments associated with barrier islands, mangroves, lagoon channels and mudflats and marshes (Besnard, 1950). This system is located in the extreme south of São Paulo coast between latitudes $24^{\circ} 5^{\prime} 00^{\prime \prime} \mathrm{S}$ and $25^{\circ} 05^{\prime} 00^{\prime \prime}$ 'S (Figure 1) limited in the north by Iguape, in the east by Ilha Comprida, in the west by Serra do Mar and in the south by Cananeia and Cardoso islands.

The present system is connected to the ocean in the north through a single channel (Barra de Icapara) and in the south through two channels (Barra de Cananeia and Ararapira). The municipal area covers 1,242,010 $\mathrm{km}^{2}$, and, according to BIGS (Brazilian Institute of Geography and Statistics), it has an estimated population of 12,220 habitants (2011 data). The main system channel is in the (Cananeia Sea), with a width of approximately 1 and $75 \mathrm{~km}$, following parallel to Ilha Comprida and with greater depth near Barra de Cananeia (6 to $7 \mathrm{~m}$ ) (Miyao et al., 1986).

\subsection{Collecting data of vulnerability parameters}

The interpretation of satellite images and aerial photography is the best way to collect data (Guebas et al., 2000; Cohen and Lara, 2003). These tools were primarily used for a large extent of land occupied by mangroves owing to the difficulty in accessibility, thus, reducing

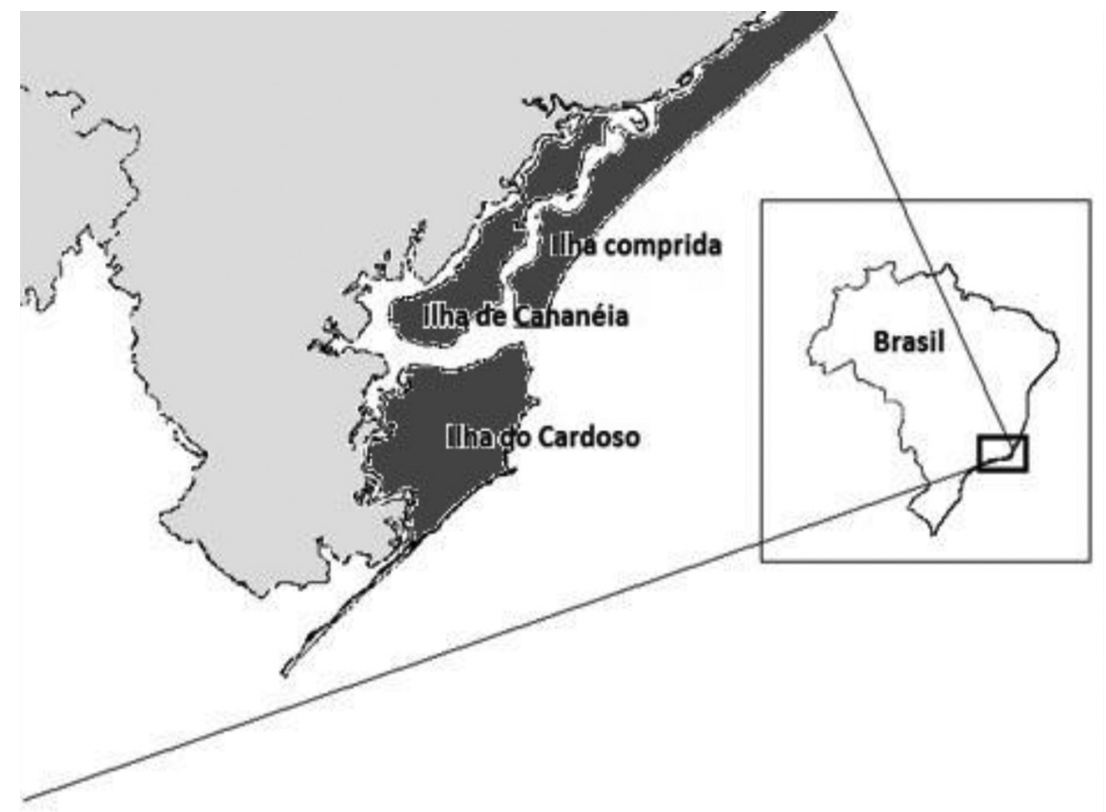

Vulnerability to erosion in mangroves

293
Figure 1. Location of the study area, the estuarine system of CananéiaIguape at the extreme south of the São Paulo coast, Brazil $\left(24^{\circ} 52^{\prime} 00^{\prime \prime} \mathrm{S} / 25^{\circ}\right.$ $05^{\prime} 00^{\prime \prime} \mathrm{S}$ and $47^{\circ}$ $55^{\prime} 00^{\prime} \mathrm{O} / 48^{\circ}$ $\left.06^{\prime} 00^{\prime \prime} \mathrm{O}\right)$ 
IJCCSM 11,2

the cost to obtain data for these estuarine systems (Kairo et al., 2002). It is necessary to highlight that a source of spatial data in a large time scale allows the comparison and detection of changes in the mangroves (Guebas et al., 2000). Besides the interpretation of such images, there remains the possibility of using other tools and processes to collect data with more detail. Thus, georeferentiation that can be described as a process of associating locations of the Earth's surface with spatial locations (Apan and Peterson, 1998) was used. Through this process, it is possible to create thematic maps or add data or information to the existing maps.

For this research, the data collected at the Water Resources Fund of São Paulo, as well as the data collected from georeferentiation, were transformed into thematic maps. Different attributes were assigned to the polygons of each parameter to create maps, through the following example: For land use, forest areas were defined as a polygon, as well as undergrowth crops, soils without covering and rural urbanization and urbanization. With this set of polygons, it was constructed a thematic map (Coelho et al., 2006).

\subsection{Evaluation and ranking of vulnerability parameters}

Several authors have used different types of parameters for the classification of vulnerability to erosion in coastal regions (the term parameter is used as a variable that allows comparisons). A thematic map that will also be used to calculate the vulnerability to erosion. Gornitz (1991) used the elevation, geology, geomorphology, shoreline displacement, tidal range, wave heights and erosion rates. Bryan et al. (2001) used the elevation, wave exposure, slope and aspect. Domínguez et al. (2005) used urbanization zones, scatter occupation zones, cropland zones and recreational and naturalistic zones. Coelho et al. (2006) used the elevation, distance to the coastline, maximum tidal range, maximum significant wave height, average rate of erosion/accretion, geology, geomorphology, land cover and anthropogenic activities. Owing to the great complexity of the mangroves, the approach used by Coelho et al. (2006) allows the selection of a larger number of parameters that represent the complex dynamics of estuarine systems (Ewel et al., 1998). According to Coelho et al. (2006), to consider the various parameters, there is a need to make a vulnerability rating for delimiting effects of critical areas. Based on these approaches (Gornitz, 1991; Bryan et al., 2001; Domínguez et al., 2005; Coelho et al., 2006), a set of parameters were defined that best characterize the mangrove areas: elevation $(\mathrm{m})$; geomorphology; geology; land cover; anthropogenic activities; distance to the coastline (m) and maximum tidal range $(\mathrm{m})$. Table I represents the set of these parameters and their assessments before the vulnerability.

The elevation reflects the susceptibility to flooding that, according to Coelho et al. (2006), differentiates the coastal areas of great slope from flat areas. Szlafsztein and Sterr (2007) explain the need to include this parameter, indicating that the lack of such data makes it difficult to quantitatively evaluate the risk of flooding and the sea level rising. It is very important to mention the existence of dunes along the coast, because these areas evidence coastal erosion, as seen in Figure 2, and the greater the elevation, the greater was the evidence of erosion. Geomorphology represents the different morphologies along the coastal region, which may be described by mountain areas, marshes, mangroves or dunes, which, according to Diez et al. (2007), is directly related to the erosion by the increase in undulation. Regarding geology, the parameter used by Gornitz (1991), Gornitz et al. (1994) and Coelho et al. (2006) allows the evaluation of the nature of the rocks and sediments of the coastal region under study, with the rock type directly connected to erosive processes. Although land use is not usually used in vulnerability ratings, this parameter was introduced to calculate the global vulnerability to erosion. Given the low socioeconomic level of the 


\begin{tabular}{|c|c|c|c|c|c|c|}
\hline $\begin{array}{l}\text { Parameter/ } \\
\text { Vulnerability }\end{array}$ & 1 - Very low & 2 -Low & 3 -Medium & 4-High & 5 - Very high & $\begin{array}{l}\text { Vulnerability } \\
\text { to erosion in }\end{array}$ \\
\hline Elevation (m) & $>30$ & $20-30$ & \multirow[b]{2}{*}{$\begin{array}{l}10-20 \\
\text { Saltwater } \\
\text { marshes } \\
\text { Mangroves } \\
\text { Coral reefs } \\
\text { Sheltered } \\
\text { beaches }\end{array}$} & $5-10$ & $<5$ & \\
\hline Geomorphology & Mountains & Rocky cliffs & & $\begin{array}{l}\text { Floodplains } \\
\text { Exposed } \\
\text { beaches } \\
\text { Estuaries }\end{array}$ & Dunes & 29 \\
\hline Geology & $\begin{array}{l}\text { Magmatic } \\
\text { rocks }\end{array}$ & $\begin{array}{l}\text { Metamorphic } \\
\text { rocks }\end{array}$ & $\begin{array}{l}\text { Sedimentary } \\
\text { rocks }\end{array}$ & $\begin{array}{l}\text { Large } \\
\text { unconsolidated } \\
\text { sediments }\end{array}$ & $\begin{array}{l}\text { Small } \\
\text { unconsolidated } \\
\text { sediments }\end{array}$ & \multirow{6}{*}{$\begin{array}{r}\text { Table I. } \\
\text { Defined parameters } \\
\text { for the study area, } \\
\text { being each attribute } \\
\text { of each parameter } \\
\text { associated with a } \\
\text { vulnerability }\end{array}$} \\
\hline Land cover & Forest & $\begin{array}{l}\text { Undergrowth, } \\
\text { crops }\end{array}$ & $\begin{array}{l}\text { Soil without } \\
\text { covering }\end{array}$ & $\begin{array}{l}\text { Rural } \\
\text { urbanization }\end{array}$ & Urbanization & \\
\hline $\begin{array}{l}\text { Anthropogenic } \\
\text { activities }\end{array}$ & $\begin{array}{l}\text { Interventions } \\
\text { with } \\
\text { maintenance } \\
\text { structures in } \\
\text { the coastline }\end{array}$ & $\begin{array}{l}\text { Interventions } \\
\text { without } \\
\text { structures, but } \\
\text { without } \\
\text { evidence } \\
\text { sedimentary } \\
\text { reduction }\end{array}$ & $\begin{array}{l}\text { Interventions } \\
\text { without } \\
\text { structures, but } \\
\text { with evidence } \\
\text { of sedimentary } \\
\text { reduction }\end{array}$ & $\begin{array}{l}\text { Without } \\
\text { interventions } \\
\text { and with no } \\
\text { evidence of } \\
\text { sedimentary } \\
\text { reduction }\end{array}$ & $\begin{array}{l}\text { Without } \\
\text { interventions, } \\
\text { but with } \\
\text { evidence of } \\
\text { sedimentary } \\
\text { reduction }\end{array}$ & \\
\hline \multirow{2}{*}{$\begin{array}{l}\text { Distance to the } \\
\text { coastline (m) } \\
\text { Maximum tidal } \\
\text { range (m) }\end{array}$} & $>1,000$ & $200-1,000$ & $50-200$ & $20-50$ & $<20$ & \\
\hline & $<1$ & $1-2$ & $2-4$ & $4-6$ & $>6$ & \\
\hline Source: Gornitz & , Dr y arrev at & ot, , & & & & \\
\hline
\end{tabular}

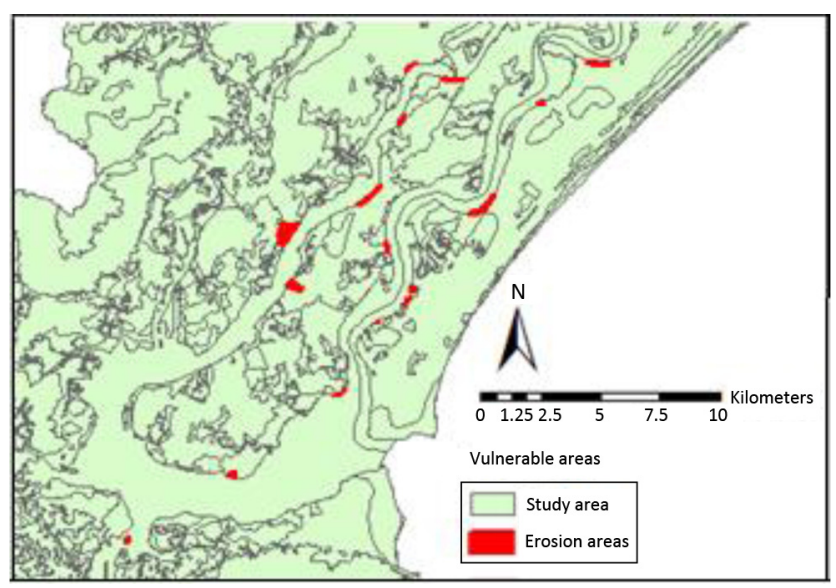

Figure 2.

Map of georeferentiation of vulnerable areas (represents the georeferentiation maps of areas with clear signs of coastal erosion)

population in this region, there is a trend of disordered land use, leading to changes in land cover, through logging large areas of forests for the infrastructure development (Casasnovas et al., 2009). Soil losses are directly linked to anthropogenic activities (Lewis and Nyamulinda, 1996). Even if you use conservation practices to reduce erosion potential, soil 
IJCCSM 11,2

296 loss rates may remain excessive (Lewis and Nyamulinda, 1996). Although some shoreline stabilization interventions are intended to reduce vulnerability, these can result in a contrary effect (Coelho et al., 2006). Vulnerability to erosion increases with proximity to the interaction zone with the sea, affecting the different land uses (Filho et al., 2006). For these reason, the distance to the coastline was used to obtain a global vulnerability map. The maximum tidal range is linked to both flooding and risk of erosion (Gornitz, 1991). Although a large tidal range dissipates wave energy, limiting the beach areas to a brief low tide period, it also defines a wide area of wetlands to be more susceptible to flooding (Gornitz, 1991). The water velocity during low tide is greater, allowing a greater movement of sediments in flood zones (Mazda et al., 1995). When the exposure index of the impact of the waves is combined with the low-lying areas, it provides a coastal vulnerability indicator (Bryan et al., 2001).

Since the parameters are in different measurement units it was necessary to classify them to allow for comparisons (Dumas et al., 2010). The rating of vulnerability ranged from 1 (very low) to 5 (very high). This can be understood in the following way: using land cover parameter as an example, the polygon (attribute) forest was replaced by 1 (very low vulnerability, for undergrowth crops by 2 , soils without covering by 3 , rural urbanization by 4 and urbanization by 5). This method was used for all parameters to be able to combine all the parameters. The rating of vulnerability (1 to 5) and the respective association with each parameter were carefully selected by the events and reality of the study area, as well as the methodologies used by Gornitz (1991), Gornitz et al. (1994), Bryan et al. (2001) and Coelho et al. (2006).

\subsection{Selecting the algorithm to combine the vulnerability parameters}

Not all algorithms represent reality just like the way it is. It is necessary to experiment various algorithms to find reliable results. At this stage, we use three different methods to combine the various vulnerability parameters.

The square root of the geometric mean used by Gornitz (1991), where $x$ is the parameter and $n$ is the total number of parameters, has been used:

$$
\begin{aligned}
& C V I=\left[\frac{1}{n}(x 1 \times x 2 \times \ldots x n)\right]^{\frac{1}{2}} \\
& x-\text { parameter } n-\text { total number of parameters }
\end{aligned}
$$

The combination of the various parameters through this method results in a global vulnerability map of the study area.

The other method, the DRASTIC index, which assigns a defined value ranging from 1 to 7 to each parameter according to their importance level (importance scale from Edet, 2004; Jamrah and Al-Futaisi, 2008).

\begin{tabular}{l|l|l|l|l|l|l|l|l}
\hline Not importante at all & 1 & 2 & 3 & 4 & 5 & 6 & 7 & Very important \\
\hline
\end{tabular}

Through this process, the standardization of the values is possible to generate a set of weights (Table II). The weights are distributed on a scale of 0 to 1 (assigning the highest values to the parameter that causes more erosion) (Edet, 2004; Jamrah and A1Futaisi, 2008). For elevation, as the impact is almost nil, the value 0.05 was assigned. As for land cover and anthropogenic activities, the highest values 0.24 and 0.22 were 
assigned, respectively. The sum of all values must be 1 (Edet, 2004; Jamrah and AlFutaisi, 2008).

Knowing the weight of each parameter, proceeding then to a weighted linear combination, giving each parameter a weight by multiplying them and adding the results, where $X$ is the individual parameter and $N$ is the assigned weight, we achieve:

$$
C V I=\sum X i \times N i
$$

Another approach for assigning weights can be achieved by using pairwise comparisons known as analytical hierarchy process (AHP). This methodology developed by Saaty (1977, 1980,1987 ) involves comparing $n$ parameters through the support of a square matrix $n \times n$, where along the columns and the rows, the parameters are arranged by the same order (Table III).

Thus $a_{i j}$ represents the relative importance of the parameter of the line $a_{i}$ relative to the parameter of the column $a_{j}$. As the matrix is reciprocal, it is only necessary to examine the lower triangular part. To standardize all pairwise comparisons, Saaty (1980) proposed a comparison of the parameters supported in five values (Table IV).

In case the parameter $a_{i}$ has a lower importance than the parameter $a_{j}$, the inverse of the number presented by the scale (Saaty, 1980) is used. Through this process, it can be defined a set of weights for each parameter, necessary for the use of the weighted linear combinations.

\begin{tabular}{lr}
\hline Parameter by order of importance & Weight \\
\hline Land cover & 0.24 \\
Anthropogenic activities & 0.22 \\
Distance to the coastline (m) & 0.18 \\
Geomorphology & 0.14 \\
Geology & 0.10 \\
Maximum tidal range (m) & 0.07 \\
Elevation (m) & 0.05
\end{tabular}

Source: Edet (2004) and Jamrah and Al-Futaisi (2008)
297

\section{Vulnerability to erosion in mangroves}

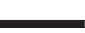

Table II.

Parameters and weights by order of importance

\begin{tabular}{lccccccc}
\hline Parameters & $\mathrm{A}$ & $\mathrm{B}$ & $\mathrm{C}$ & $\mathrm{D}$ & $\mathrm{E}$ & $\mathrm{F}$ & $\mathrm{G}$ \\
\hline $\mathrm{A}$ & 1 & 3 & 3 & 5 & 7 & 7 & 9 \\
$\mathrm{~B}$ & $1 / 3$ & 1 & 1 & 3 & 3 & 7 & 7 \\
$\mathrm{C}$ & $1 / 3$ & 1 & 1 & 3 & 3 & 5 & 7 \\
$\mathrm{D}$ & $1 / 5$ & $1 / 3$ & $1 / 3$ & 1 & 1 & 5 & 7 \\
$\mathrm{E}$ & $1 / 7$ & $1 / 3$ & $1 / 3$ & 1 & 1 & 5 & 7 \\
$\mathrm{~F}$ & $1 / 7$ & $1 / 7$ & $1 / 5$ & $1 / 5$ & $1 / 5$ & 1 & 5 \\
$\mathrm{G}$ & $1 / 9$ & $1 / 7$ & $1 / 7$ & $1 / 7$ & $1 / 7$ & $1 / 5$ & 1
\end{tabular}

Notes: $\mathrm{A}$ criterion $=$ land cover; $\mathrm{B}$ criterion $=$ anthropogenic activities; $\mathrm{C}$ criterion $=$ distance to the coastline; $\mathrm{D}$ criterion $=$ geomorphology $\mathrm{E}$ criterion $=$ geology $; \mathrm{F}$ criterion $=$ maximum tidal range; $\mathrm{G}$ criterion = elevation

Source: Saaty $(1977,1987,1980)$

Table III.

Saaty's matrix matrices for evaluating the relative importance of the seven criteria 


\section{IJCCSM 11,2}

298

\section{Findings}

The overall vulnerability maps were built using three different models to match the parameters of a region Figures 3-5).

As would be expected, different algorithms have different global vulnerability results. There is a need to emphasize in these three maps the high level of very high vulnerability represented on the maps in which we used the weighted linear sum in relation to the map with the approach of the square root of the geometric mean. Another fact that stands out in the use of weighted linear combination is the over-represented areas with high vulnerability, which highlight a higher percentage for the case where we used the DRASTIC index. On the other hand, the use of the square root of the geometric mean urged higher percentage of occupied area with low and very low vulnerability. Although the use of the method based on pairwise comparisons has similarities to the model where the square root of the geometric mean was used, it represents a larger percentage of the areas with medium to very high vulnerability compared to the model of the square root of the geometric mean. These three examples show the discrepancies between the models, which may mislead the user, in case he has no knowledge about the reality of the study area.

Figure 6 groups all vulnerability maps by applying the square root of the geometric mean, resulted in the global vulnerability map of the study area.

\section{Discussion}

Typically, mangroves of tropical and sub-tropical regions are of great importance from the point of view of not only the resources they provide but also the protection they offer to local regions and the animal community (Mazda et al., 2002). Such forest systems have been used as a source of renewable resources (Manassrisuksi et al., 2001). But, the pressure generated with the increase in population in these regions has increased the over-exploitation of resources (Manassrisuksi et al., 2001). These pressures, combined with the natural dynamics of these systems, have been increasing the erosive processes, resulting in a decrease of the areas occupied by mangroves (Filho et al., 2006). Large parts of these forest areas eventually disappear because the balance changes between losses and sediment inputs are so critical that human intervention is necessary to help the regeneration of mangroves (Cohen and Lara, 2003; Filho et al., 2006). To adjust these changes, the identification of a set of parameters of evaluation and prediction becomes essential for determining the factors that most influence the erosion. The parameters defined and determined in this work to ascertain the coastal erosion vulnerability in mangroves proved to be suitable for the development of a model for the estuarine system of Cananéia-Iguape, São Paulo, Brazil. The multidisciplinary approach by means of adapting the study to a set of validated models for other geographical areas and different coastal systems allowed to represent the reality in the study area in a special model that represented the vulnerability to erosion, which is a

Table IV.

Scale ranks

\begin{tabular}{ll}
\hline Value & Definition \\
\hline 1 & Equal importance \\
3 & Weak importance \\
5 & Essential or strong importance \\
7 & Demonstrated importance \\
9 & Absolute importance \\
Source: Saaty $(1977,1987,1980)$ & \\
\hline
\end{tabular}




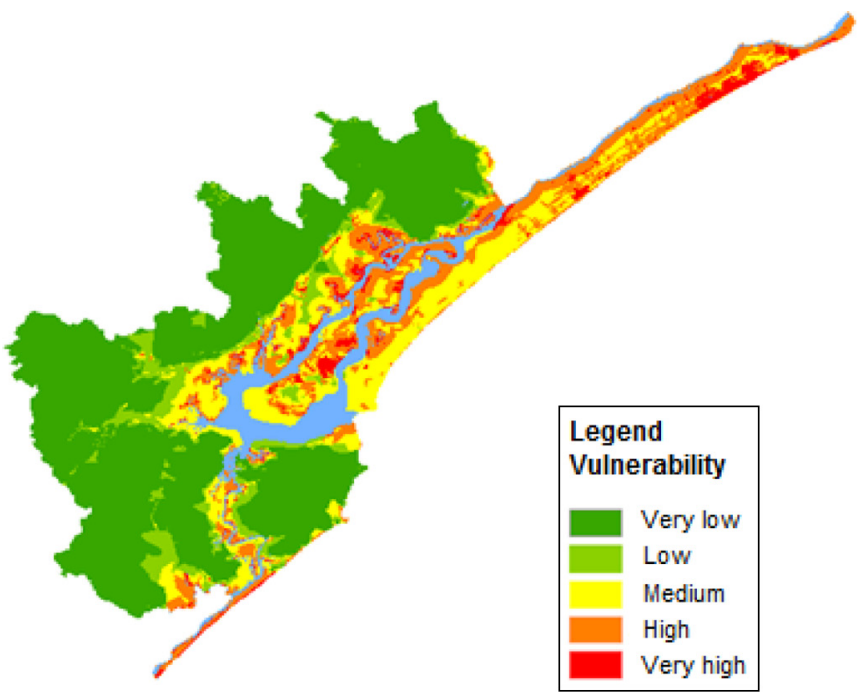

\section{Vulnerability to erosion in mangroves}

25

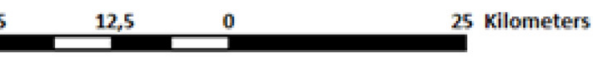

Source: Gornitz (1991)
$\stackrel{N}{N}$

Figure 3. Erosion vulnerability map (square root of the geometric mean)

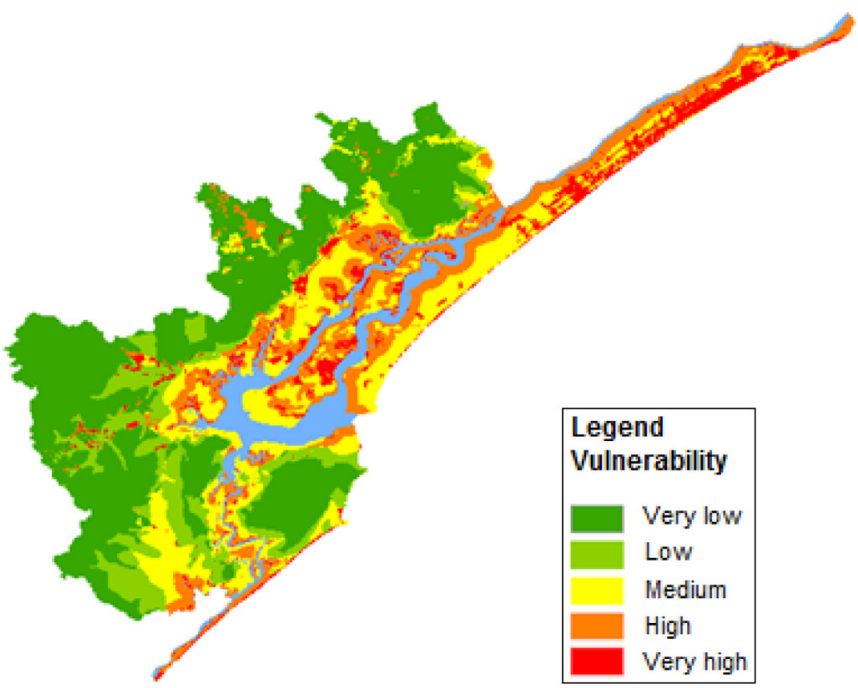

$N$

25 12,5 0 25 Kilometers

Source: Saaty $(1977,1987,1980)$

Figure 4.

Erosion vulnerability map (method based on pairwise comparisons) 
IJCCSM

11,2

300

Figure 5.

Erosion vulnerability map (DRASTIC index)
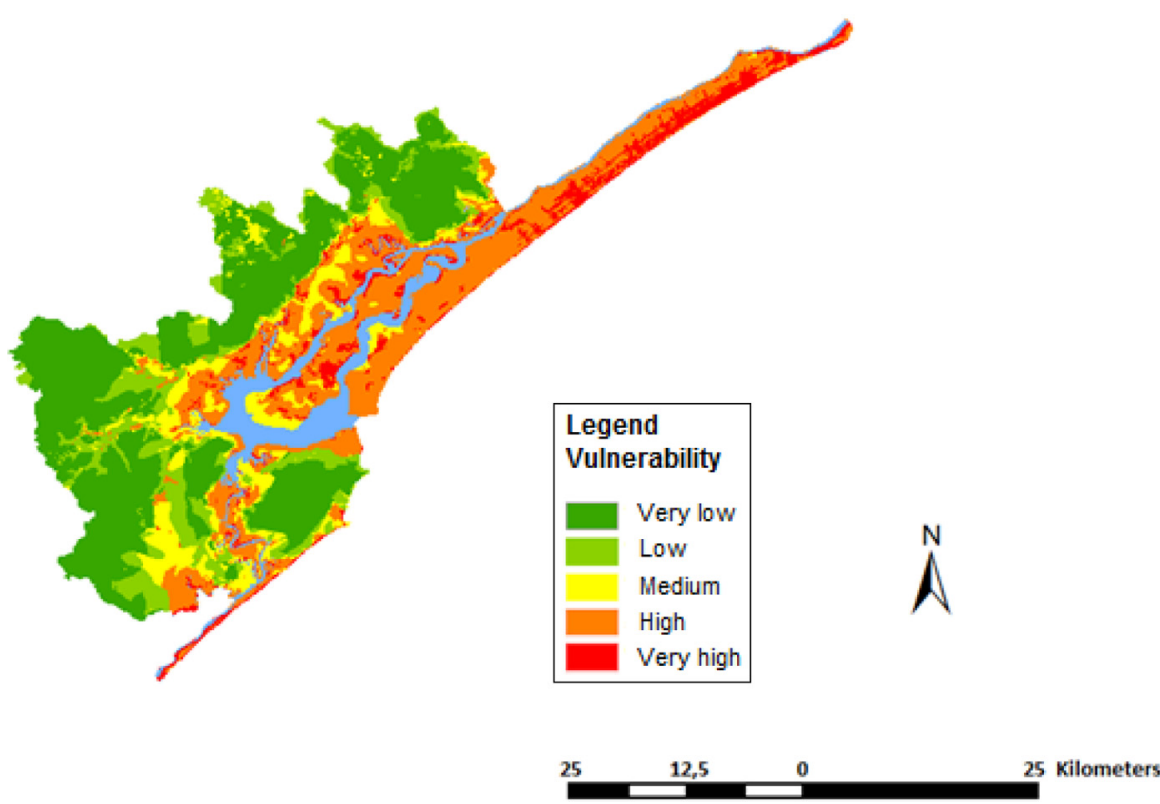

Source: Jamrah and Al-Futaisi (2008)

fundamental tool for the management of the estuarine system of Cananeia-Iguape, São Paulo, Brazil. To evaluate the performance of erosion risk models and validate them for different conditions of soil management, it is necessary to examine and compare the results obtained with multiple studies that have been conducted in other geographical areas.

The analysis of the complex interactions that take place on a large scale and the processes taking place in the region of study is necessary to help to choose the best model to calculate the global vulnerability (Cozannet et al., 2013). The three approaches described in this study contributed to a better understanding of the spatial distribution of erosion vulnerability. Although they use the same input parameters, the results obtained following the use of different algorithms showed some significant differences, and critical thinking should be involved in choosing the best option. The use of weighted linear combination has the advantage of being able to shape the different study areas, by assigning weights (Store and Kangas, 2001). The overvaluation of parameters seemed to be an issue that needs a more detailed approach in the near future, because it has shaped the results (Pereira and Coelho, 2013). The use of the square root of the geometric mean appears to be unstable to small changes in parameters (Diez et al., 2007). The diversion of the category of one of the variables regarding the others can change the results substantially, thus representing major changes in vulnerability analysis (Diez et al., 2007).

The developed model is adequate for the analysis of the global vulnerability coastal erosion distribution, and it constitutes a valid qualitative method, based on a cognitive approach that permits the definition of vulnerability parameters, rating parameters over a range of values and the combination of parameters that best suit the complexity of mangroves for determining the vulnerability of coastal erosion. A multidisciplinary approach with appropriate information was developed by adapting the study area to a set of 


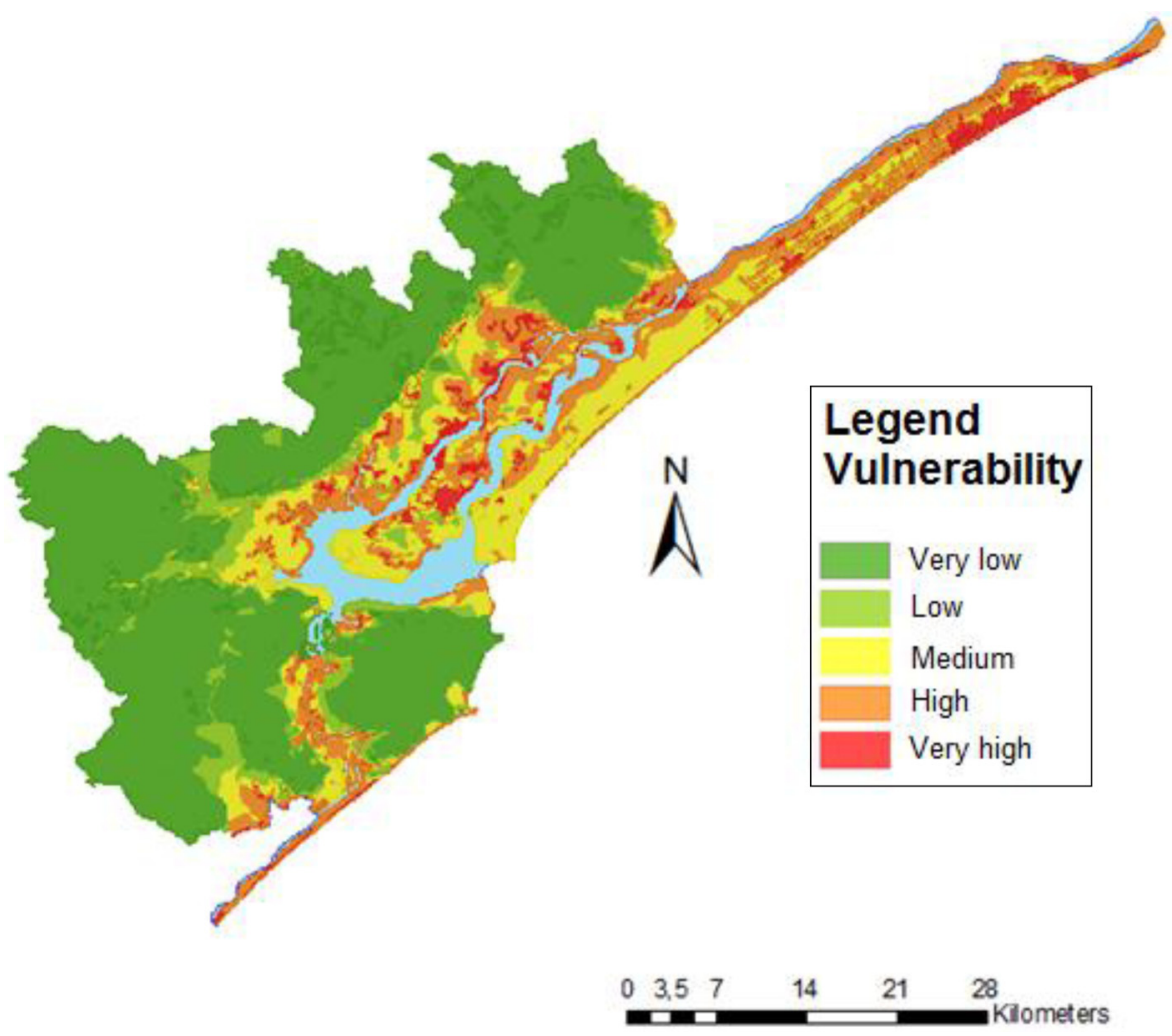

Vulnerability to erosion in mangroves

301

Figure 6. Global vulnerability map of the estuarine system of CananéiaIguape

already existing and validated models, rendering a model that represents the vulnerability to erosion and constitutes a fundamental tool for the management of these systems (Szlafsztein and Sterr, 2007; Rao et al., 2009; Gornitz, 1991; Gornitz et al., 1994; Edet, 2004; Coelho et al., 2006).

The information provided by GIS allows various combinations that may be used to solve numerous issues involving essential spatial data to access a sustainable territorial management dynamics (Carver, 1991). The main advantage of using GIS regarding other methods is its ability to store, modify and retrieve large sets of heterogeneous data source and to represent them in a visual format (Krause et al., 2004). The use of these tools depends on the quality, availability and accuracy of the data (Krause et al., 2004). The application of GIS to quantify and mapping the set of variables that contribute to the evaluation of erosion risk due to environmental pressures (droughts, floods, loss of land, rising temperatures, and rising sea levels) is a very valuable tool. Applications in population displacement and migrations, increasing pressures on urban infrastructure and services, increasing risks of conflicts and social unrest and spreading health risks (Boulanger and Brechet, 2005) provide scientific support to decision-making.

The development of regular and continuous studies to predict the behavior of erosion and prevent the degradation of coastal ecosystems can be useful in the planning and management of population displacement mainly due to climate change impacts (Lewis and 
IJCCSM 11,2

Nyamulinda, 1996; Jones, 2001; Freeman and Kunreuther, 2002, Warner and Laczko, 2008a, 2008b; Warner et al., 2008), The Intergovernmental Panel on Climate Change (IPCC, 2007a) in the Fourth Assessment Report describes six climate change scenarios including a variety of impacts such as loss of coastal lands, flooding that could displace hundreds of millions of people, extreme weather events, stress on regional water supplies and significant biodiversity loss. These impacts create both direct effects (i.e. rapid sea rise, coastal erosion and food scarcity) and indirect effects (i.e. migrations and poverty). The stress caused by climate change will exacerbate resource competition for food, water and other necessities. The application of this approach will develop a variety of new methodologies with different types of applications that not only identify the most vulnerable areas but also calculate erosion rates (Dumas et al., 2010) and can also be useful in planning population displacement (e.g., prediction of the magnitude of soil loss by erosion and quantification of the risk and vulnerability). Today the use of GIS as a spatial information processing tool and the use of a set of computational procedures that enable and facilitate analysis, representation and management of areas and phenomena that occur (Chrisman, 2001) are very common.

\section{Conclusions}

Simulation studies of prediction models developed for coastal erosion are crucial for preventing the degradation of coastal ecosystems. Also integrated solutions to uncontrolled population growth and urbanization in coastal areas, poverty and economic inequality in coastal communities are urgently needed. This global warming and climate change scenario, with impacts on the infrastructure, leading to population displacement, requiring adaptation and mitigation options supported by science-based strategies and solutions, and these models can be useful in planning population displacement.

Estimates of the vulnerability and integrated coastal zone management in the context of climate change adaptation should also adopt participatory monitoring measures and progress evaluation.

\section{References}

Adger, W.N. (2006), "Vulnerability”, Global Environmental Change, Vol. 16 No. 3, pp. 268-281.

Allen, J.A., Ewel, K.C. and Jack, J. (2001), "Patterns of natural and anthropogenic disturbance of the mangroves on the pacific island of Kosrae", Wetlands Ecology and Management, Vol. 9, pp. 279-289.

Alongi, D.M. (2002), "Present state and future of the worlds mangrove forests", Environmental Conservation, Vol. 29 No. 3, pp. 331-349.

Alongi, D.M. (2008), "Mangrove forests: resilience, protection from tsunamis, and responses to global climate change", Estuarine Coastal and Shelf Science, Vol. 76 No. 1, pp. 1-13.

Alongi, D.M. (2009), "Paradigm shifts in mangrove biology", in Wolanski, E., Cahoon, D. and Perillo, G. M.E. (Eds), Coastal Wetlands: An Ecosystem Integrated Approach, Elsevier Science, Amsterdam, pp. 615-640.

Amorim, R., Silva, D., Pruski, F. and Matos, A. (2010), “Avaliação do desempenho dos modelos de predição da erosão hídrica USLE, RUSLE e WEPP Para diferentes condições edafoclimáticas do BRASIL”, Engenharia Agricola, Vol. 30 No. 6, pp. 1046-1049.

Angima, S., Stott, D., O'neill, M., Ong, C. and Weesies, G. (2003), "Soil erosion prediction using RUSLE for Central Kenyan highland conditions", Agriculture, Ecosystems and Environment, Vol. 97 Nos 1/3, pp. 295-308.

Apan, A.A. and Peterson, J.A. (1998), "Probing tropical deforestation”, Applied Geography, Vol. 18 No. 2, pp. 137-152. 
Area, N.P., Collins, F. and Leuven, K.U. (1998), "The European soil erosion model (EUROSEM): a dynamic approach for predicting sediment transport from fields and small catchments", Earth Surface Processes and Landforms, Vol. 23 No. 6, pp. 527-544.

Barnett, J. (2006), “Climate change, insecurity and injustice”, in Adger, W.N., Paavola, J., Huq, S. and Mace, M.J. (Eds), Fairness in Adaptation to Climate Change, MIT Press, Cambridge, MA, pp. 115-129.

Berkhout, F., Hertin, J. and Gann, D.M. (2006), "Learning to adapt: organizational adaptation to climate change impacts", Climate Change, Vol. 78 No. 1, pp. 135-156.

Besnard, W. (1950), "Considerações gerais em tôrno da região lagunar de Cananéia-Iguape: I", Boletim Do Instituto Paulista De Oceanografia, Vol. 1 No. 1, pp. 9-26.

Black, R., Kniveton, D., Skeldon, R., Coppard, D., Murata, A. and Schmidt-Verkerk, K. (2008), "Demographics and climate change: future trends and their policy implications for migration". Report prepared for the Department for International Development (DFID) by the Development Research Centre on Migration, Globalisation and Poverty, University of Sussex.

Boulanger, P.M. and Brechet, T. (2005), "Models for policy-making in sustainable development: the state of the art and perspectives for research", Ecological Economics, Vol. 55 No. 3, pp. 337-350.

Brinkman, R.M. (2006), Wave Attenuation in Mangrove Forests: An Investigation through Field and Theoretical Studies, James Cook University, Townsville, p. 146.

Bryan, B., Harvey, N., Belperio, T. and Bourman, B. (2001), "Distributed process modeling for regional assessment of coastal vulnerability to sea-level rise", Environmental Modeling and Assessment, Vol. 6 No. 1, pp. 57-65.

Burger, B. (2005), "Wave attenuation in mangrove forests numerical modelling of wave attenuation by implementation of a physical description of vegetation in SWAN", MSc thesis, Faculty of Civil Engineering and Geosciences Section of Hydraulic Engineering.

Carver, S.J. (1991), "International journal of geographical information systems integrating multi-criteria evaluation with geographical information systems geographical information systems", International Journal of Geographical Information Systems, Vol. 5 No. 3, pp. 321-339.

Casasnovas, J.A.M., Ramos, M.C. and Hernández, D.G. (2009), "Effects of land-use changes in vegetation cover and sidewall erosion in a gully head of the Penedès region (northeast Spain)", Earth Surface Processes and Landforms, Vol. 34 No. 14, pp. 1927-1937.

Chrisman, N. (2001), Exploring Geographic Information Systems, 2nd ed., Wiley, New York, NY.

Coelho, C., Veloso, R.S.F. and Pinto, F.T. (2006), "Modelos de previsão da evolução da configuração costeira risk evaluation: predictive models of coastal configuration evolution", 1as Jornadas de Hidráulica, Recursos Hidricos e Ambiente, Porto, pp. 17-25.

Cohen, M.C.L. and Lara, R.J. (2003), "Temporal changes of mangrove vegetation boundaries in Amazonia: application of GIS and remote sensing techniques", Wetlands Ecology and Management, Vol. 11 No. 4, pp. 223-231.

Cozannet, G., Garein, M., Bulteau, T., Yates, M., Mendez, M., Bails, A., Idier, D. and Oliveros, C. (2013), "An AHP-derived method for mapping the physical vulnerability of coastal areas at regional scales”, Natural Hazards and Earth System Science, Vol. 13 No. 5, pp. 1209-1227.

Diez, P.G., Perillo, G.M.E. and Piccolo, M.C. (2007), "Vulnerability to sea-level rise on the coast of the Buenos Aires province", Journal of Coastal Research, Vol. 231, pp. 119-126.

Domínguez, L., Anfuso, G. and Gracia, F.J. (2005), "Vulnerability assessment of a retreating Coast in SW Spain”, Environmental Geology, Vol. 47 No. 8, pp. 1037-1044.

Dumas, P., Prontemps, J., Mangeas, M. and Luneau, G. (2010), "Developing erosion models for integrated coastal zone management: a case study of the New Caledonia West Coast", Marine Pollution Bulletin, Vol. 61 Nos 7/12, pp. 519-529.

Edet, A.E. (2004), "Vulnerability evaluation of a coastal plain sand aquifer with a case example from Calabar, southeastern Nigeria”, Environmental Geology, Vol. 45 No. 8, pp. 1062-1070. 
IJCCSM 11,2
Ellison, J.C. (2015), "Vulnerability assessment of mangroves to climate change and sea-level rise impacts", Wetlands Ecology and Management, Vol. 23 No. 2, pp. 115-137.

Ericson, J.P., Vorosmarty, C.J., Dingman, S.L., Ward, L.G. and Meybeck, M. (2006), "Effective sea-level rise and deltas: causes of change and human dimension implications", Global Planet Change, Vol. 50 Nos 1/2, pp. 63-82.

Ewel, K.C., Twilley, R.R. and Ong, J.E. (1998), "Kinds of mangrove forests provide different goods and services", Global Ecology and Biogeography Letters, Vol. 7 No. 1, pp. 83-94.

Field, C.D. (1995), "Impact of expected climate change on mangroves. in Wong, Y.S. and Tam, N.F.Y. (Eds), Asia-Pacific Symposium on Mangrove Ecosystems, Springer, pp. 75-81.

Filho, P.W.M.S., Martins, E.S.F. and Costa, F.R. (2006), "Using mangroves as a geological indicator of coastal changes in the Bragança macrotidal flat, Brazilian Amazon: a remote sensing data approach", Ocean and Coastal Management, Vol. 49 Nos 7/8, pp. 462-475.

Freeman, P.K. and Kunreuther, H. (2002), "Environmental risk management for developing countries", Geneva Papers on Risk and Insurance - Issues and Practice, Vol. 27 No. 2, pp. 196-214.

Gilman, E., Ellison, J.C., Duke, N.C., Field, C. and Fortuna, S. (2008), “Threats to mangroves from climate change and adaptation options: a review", Aquatic Botany, Vol. 89 No. 2, pp. 237-250.

Gomes, F.V. (2007), “A gestão da zona costeira Portuguesa”, Revista Da Gestão Costeira Integrada, Vol. 7 No. 2, pp. 83-95.

Gornitz, V. (1991), "Global coastal hazards from future sea level rise”, Palaeogeography, Palaeoclimatology, Palaeoecology, Vol. 89 No. 4, pp. 379-398.

Gornitz, V., Daniels, R., White, T. and Birdwell, K. (1994), "The development of a coastal risk assessment database: vulnerability to sea-level rise in the US southeast", Journal of Coastal Research, Vol. 12, pp. 327-338.

Guebas, F., Verheyden, A., Genst, W., Hettiarachchi, S. and Koedam, N. (2000), "Four decade vegetation dynamics in Sri Lankan mangroves as detected from sequential aerial photography: a case study in Galle", Bulletin of Marine Science, Vol. 67 No. 2, pp. 741-759.

Intergovernmental Panel on Climate Change (IPCC) (2007a), Climate Change 2007: Synthesis Report. Contribution of Working Groups I, II, and III to the Fourth Assessment Report of the Intergovernmental Panel on Climate Change, Intergovernmental Panel on Climate Change, Geneva.

IPCC (2007b), "Climate change 2007: the physical science basis”, in Solomon, S., Qin, D., Manning, M., Chen, Z., Marquis, M., Averyt, K.B., Tignor, M. and Miller, H.L. (Eds), Contribution of Working Group I to the Fourth Assessment Report of the Intergovernmental Panel on Climate Change, Cambridge University Press, Cambridge and New York, NY.

IPCC (2007c), "Climate change 2007: impacts, adaptation and vulnerability”, in Parry, M.L., Canziani, O. F., Palutikof, J.P., van der Linden, P.J. and Hanson, C.E. (Eds), Contribution of Working Group II to the Fourth Assessment Report of the Intergovernmental Panel on Climate, Cambridge University Press, Cambridge.

Jamrah, A. and Al-Futaisi, A. (2008), "Assessment of groundwater vulnerability in the coastal region of Oman using DRASTIC index method in GIS environment”, Environmental Monitoring and Assessment, Vol. 147 Nos 1/3, pp. 125-138.

Jones, R.N. (2001), “An environmental risk assessment/management framework for climate change impact assessments”, Natural Hazards, Vol. 23, pp. 197-230.

Kairo, J.G., Kivyatu, B. and Koedam, N. (2002), "Application of remote sensing and GIS in the management of mangrove forests within and adjacent to Kiunga marine protected area", Environment, Development and Sustainability, Vol. 4 No. 2, pp. 153-166.

Keisler, J.M. and Sundell, R.C. (1997), "Information for boundary decisions: an application to park planning", Journal of Geographic Information and Decision Analysis, Vol. 1 No. 2, pp. 100-119. 
Kibreab, G. (1997), "Environmental causes and impact of refugee movements: a critique of the current debate", Disasters, Vol. 21 No. 1, pp. 20-38.

Krause, G., Bock, M., Weiers, S. and Braun, G. (2004), "Mapping land-cover and mangrove structures with remote sensing techniques: a contribution to a synoptic GIS in support of coastal management in North Brazil", Environmental Management, Vol. 34 No. 3, pp. 429-440.

Krauss, K.W., Lovelock, C.E., McKee, K.L., Lopez-Hoffman, L., Ewe, S.M.L. and Sousa, W.P. (2008), "Environmental drivers in mangrove establishment and early development", Aquatic Botany, Vol. 89 No. 2, pp. 105-127.

Lamari, M., Bouchard, J., Jacob, J. and Poulin-Larivière, L. (2016), "Monitoring and evaluation of climate change adaptation in coastal zones: overview of the indicators in use" in Filho, W.L., Musa, H., Cavan, G., O'Hare, P. and Seixas, J. (Eds), Climate Change Adaptation, Resilience and Hazards, Springer International Publishing, pp. 3-20, ISBN 978-3-319-39879-2.

Lewis, L. and Nyamulinda, V. (1996), "The critical role of human activities in land degradation in Rwanda", Land Degradation \& Development, Vol. 7 No. 1, pp. 47-55.

Lin, C.-Y., Lin, W.-T. and Chou, W.-C. (2002), "Soil erosion prediction and sediment yield estimation: the Taiwan experience", Soil and Tillage Research, Vol. 68 No. 2, pp. 143-152.

McIvor, A.L., Möller, I., Spencer, T. and Spalding, M. (2012), Reduction of Wind and Swell Waves by Mangroves, Cambridge Coastal Research Unit, Cambridge, p. 7.

McKee, K.L., Rogers, K. and Saintilan, N. (2012), "Response of salt marsh and mangrove wetlands to changes in atmospheric CO2, climate, and sea level", in Middleton, B. (Ed.), Global Change and the Function and Distribution of Wetlands, Springer, Dordrecht, pp. 63-96.

McLeman, R. and Smit, B. (2006), "Migration as an adaptation to climate change", Climatic Change, Vol. 76 Nos 1/2, pp. 31-53.

McLeod, E., Chmura, G.L., Bouillon, S., Salm, R., Bjork, M., Duarte, C.M., Lovelock, C.E., Schlesinger, W. H. and Silliman, B.R. (2011), "A blueprint for blue carbon: toward an improved understanding of the role of vegetated coastal habitats in sequestering CO22", Frontiers in Ecology and the Environment, Vol. 9 No. 10, pp. 552-560.

Manassrisuksi, K., Weir, M. and Ali, Y. (2001), “Assessment of a mangrove rehabilitation programme using remote sensing and GIS: a case study of Amphur Khlung, Chantaburi province, eastern Thailand", The 22nd Asian Conference on Remote Sensing ACRS, pp. 1338-1343.

Mazda, Y., Kanazawa, N. and Wolanski, E. (1995), "Tidal asymmetry in mangrove creeks", Hydrobiologia, Vol. 295 Nos 1/3, pp. 51-58.

Mazda, Y., Magi, M., Nanao, H., Kogo, M., Miyagi, T., Kanazawa, N. and Kobashi, D. (2002), "Coastal erosion due to long-term human impact on mangrove forests", Wetlands Ecology and Management, Vol. 10 No. 1, pp. 1-9.

Miyao, S.Y., Nishihara, L. and Sarti, C.C. (1986), "Características físicas e químicas do sistema estuarinolagunar de cananéia-iguape", Boletim Do Instituto Oceanográfico, Vol. 34, pp. 23-36.

Nas, B., Cay, T., Iscan, F. and Berktay, A. (2010), "Selection of MSW landfill site for Konya, Turkey using GIS and multi-criteria evaluation", Environmental Monitoring and Assessment, Vol. 160 Nos 1/4, pp. 491-500, doi: 10.1007/s10661-008-0713-8.

Nicholls, R.J. and Tol, R.S.J. (2006), "Impacts and responses to sea-level rise: a global analysis of the SRES scenarios over the 21st century", Philosophical Transactions of the Royal Society B, Biological Sciences, Vol. 364 No. 1841, pp. 1073-1095.

Paavola, J. and Adger, W.N. (2006), "Fair adaptation to climate change", Ecological Economics, Vol. 56 No. 3, pp. 594-609, doi: 10.1016/j.ecolecon.2005.03.015.

Pelling, M. and Hight, S. (2005), "Understanding adaptation: what can social capital offer assessments of adaptive capacity?", Global Environmental Change, Vol. 15 No. 4, pp. 308-319.

Perch-Nielsen, S.L., Bättig, M.B. and Imboden, D. (2008), "Exploring the link between climate change and migration", Climatic Change, Vol. 91 Nos 3/4, pp. 375-393.
Vulnerability to erosion in mangroves 
IJCCSM 11,2

Pereira, C. and Coelho, C. (2013), "Mapas de risco das zonas costeiras por efeito da ação energética do mar", Revista De Gestão Costeira Integrada, Vol. 13 No. 1, pp. 27-43.

Rao, K., Subraelu, P., Rao, T., Malini, B., Ratheesh, R., Bhattacharya, S., Rajawat, A. and Ajai, (2009), "Sea-level rise and coastal vulnerability: an assessment of Andhra Pradesh Coast, India through remote sensing and GIS", Journal of Coastal Conservation, Vol. 12 No. 4, pp. 195-207.

Reuveny, R. (2007), "Climate change-induced migration and violent conflict", Political Geography, Vol. 26 No. 6, pp. 656-673.

Saaty, T.L. (1977), “A scaling method priorities in hierarchical structures”, Journal of Mathematical Psychology, Vol. 15 No. 3, pp. 234-281.

Saaty, T.L. (1980), The Analytic Hierarchy Process: Planning, Priority Setting, Resource Allocation, Mcgraw-Hill, New York, NY.

Saaty, T.L. (1987), "Concepts, theory and techniques: rank generation, preservation, and reversal in the analytic hierarchy decision process", Decision Sciences, Vol. 18 No. 2, pp. 157-177.

Schiereck, G.J. and Booij, N. (1995), "Wave transmission in mangrove forests", Proceeding of Copedec 1996, Rio de Janeiro.

Seidl, R., Rammer, W. and Lexer, M.J. (2011), "Climate change vulnerability of sustainable Forest management in the Eastern alps", Climatic Change, Vol. 106 No. 2, pp. 225-254.

Smith, T.J., III., Robblee, M.B., Wanless, H.R. and Doyle, T.W. (1994), "Mangroves, hurricanes, and lighming strikes", Biotierace, Vol. 44 No. 4, pp. 256-262.

Spalding, M., Blasco, F. and Field, C. (1997), World Mangrove Atlas, The International Society for Mangrove Ecosystems, Okinawa, p. 178.

Store, R. and Kangas, J. (2001), "Integrating spatial multi-criteria evaluation and expert knowledge for GIS-based habitat suitability modelling", Landscape and Urban Planning, Vol. 55 No. 2, pp. 79-93.

Suzuki, T., Zijlema, M., Burger, B., Meijer, M.C. and Narayan, S. (2012), "Wave dissipation by vegetation with layer schematization in SWAN", Coastal Engineering, Vol. 59 No. 1, pp. 64-71.

Syvitski, J.P.M. (2008), "Deltas at risk", Sustainability Science, Vol. 3 No. 1, pp. 23-32, doi: 10.1007/ s11625-008-0043-3.

Syvitski, J.P.M., Kettner, A.J., Overeem, I., Hutton, E.W.H., Hannon, M.T., Brakenridge, G.R., Day, J., Vörösmarty, C., Saito, Y., Giosan, L. and Nicholls, R.J. (2009), "Sinking deltas due to human activities”, Nature Geoscience, Vol. 2 No. 10, pp. 681-686.

Szlafsztein, C. and Sterr, H. (2007), "A GIS-based vulnerability assessment of coastal natural hazards, state of Pará”, Brazil”, Journal of Coastal Conservation, Vol. 11 No. 1, pp. 53-66.

Thampanya, U., Vermaat, J.E., Sinsakul, S. and Panapitukkul, N. (2006), "Coastal erosion and mangrove progradation of Southern Thailand", Estuarine, Coastal and Shelf Science, Vol. 68 Nos 1/2, pp. 75-85.

Vo-Luong, P. and Massel, S. (2008), "Energy dissipation in non-uniform mangrove forests of arbitrary depth", Journal of Marine Systems, Vol. 74 Nos 1/2, pp. 603-622.

Ward, R.D., Friess, D.A., Day, R.H. and MacKenzie, R.A. (2016), "Impacts of climate change on mangrove ecosystems: a region by region overview", Ecosystem Health and Sustainability, Vol. 2 No. 4, doi: 10.1002/ehs2.1211.

Warner, K. and Laczko, F. (2008a), "A global research agenda: climate change and displacement", Forced Migration Review, Vol. 31, pp. 59-60.

Warner, K. and Laczko, F. (2008b), "Migration, environment and development: new directions for research", in Chamie, J. and Dall"Oglio, L. (Eds), International Migration and Development, Continuing the Dialogue: Legal and Policy Perspectives, International Organization for Migration (IOM), Geneva and Center for Migration Studies (CMS), New York, NY.

Warner, K., Dun, O. and Stal, M. (2008), "Field observations and empirical research. Climate change and displacement”, Forced Migration Review, Vol. 31, pp. 13-14. 
Warren, R., Arnell, N., Nicholls, R., Levy, P. and Price, J. (2006), "Understanding the regional impacts of climate change", Research Report Prepared for the Stern Review on the Economics of Climate Change, September 2006, Research Working Paper 90, Tyndall Centre for Climate Change, Oxford.

Vulnerability to erosion in mangroves

Wilbanks, T.J., Leiby, P., Perlack, R., Ensminger, J.T. and Wright, S.B. (2007), "Toward an integrated analysis of mitigation and adaptation: some preliminary findings", Mitigation and Adaptation Strategies for Global Change, Vol. 12 No. 5, pp. 713-725.

WMO (2011), Space and Climate Change. Use of Space-Based Technologies in the United Nations System, World Meteorological Organization, No. 1081, p. 54.

Woodroffe, C.D. (2002), Coasts: Form, Process and Evolution, Cambridge University Press, Cambridge.

Zhang, K.Q., Liu, H., Li, Y., Hongzhou, X., Jian, S., Rhome, J. and Smith, T.J., III (2012), "The role of mangroves in attenuating storm surges", Estuarine, Coastal and Shelf Science, Vols 102/103, pp. 11-23.

\section{Corresponding author}

Ulisses Azeiteiro can be contacted at: ulisses@ua.pt

For instructions on how to order reprints of this article, please visit our website: www.emeraldgrouppublishing.com/licensing/reprints.htm Or contact us for further details: permissions@emeraldinsight.com 